\title{
Environmental and Social Value of Natural Gas
}

Natural gas, as a clean energy source, can reduce the economic losses caused by environmental pollution from coal and petroleum. Based on international experience of natural gas consumption development, it is clear that, while natural gas lacks an obvious price advantage and has even higher direct costs, it is still an effective substitute for other energy sources. The key to this is that restricting pollution reduces the economic and social losses associated with pollution.

\subsection{Losses Caused by Atmospheric Pollution in China}

\subsubsection{Atmospheric Pollution is a Key Cause of Death in China}

Based on World Health Organization figures, in 2010 there were 1.2 million people who died prematurely as a result of air pollution, representing a loss of over 25 million years of healthy living. Atmospheric pollution includes indoor and outdoor pollution, among which outdoor

\footnotetext{
* This chapter was overseen by Zhaoyuan $\mathrm{Xu}$ from the Development Research Center of the State Council and Martin Haigh from Shell International, with contributions from Baosheng Zhang and Shouhai Chen from the China University of Petroleum, Lianzeng Zhao from the China Petroleum Planning Research Institute, Linji Qiao from ENN and Juan Han from Shell China. Other members of the research group participated in discussions and revisions.
}

pollution is mainly caused by discharge of pollutants through the use of fossil fuels, including coal burning, automobile emissions, dust, etc., while indoor atmospheric pollution is caused by leakage of hazardous substances generated during finishing, and the lack of affordable and clean fuels for residential use; an example of this is the use of direct combustion of large quantities of coal briquettes, which cause significant pollution. In 2010, outdoor atmospheric pollution was ranked fourth as a cause of death for residents in China, while indoor atmospheric pollution was ranked fifth.

From a historical point of view, prevention of indoor atmospheric pollution in China has improved a great deal, but outdoor atmospheric pollution still presents serious challenges. In 1990, indoor atmospheric pollution was ranked second as a cause of death in China. Subsequently, its importance dropped rapidly, and in 2010, it was ranked fifth. However, in recent years, with rapid economic development in China, and a lack of strict energy conservation and emission reduction measures in many energy production and consumption enterprises, the air quality in China has failed to improve significantly, and the threat of atmospheric pollution to health remains significant. During the period 1990-2010, an average of 80-90 persons per 10,000 died of various diseases caused by atmospheric pollution (Fig. 4.1). 


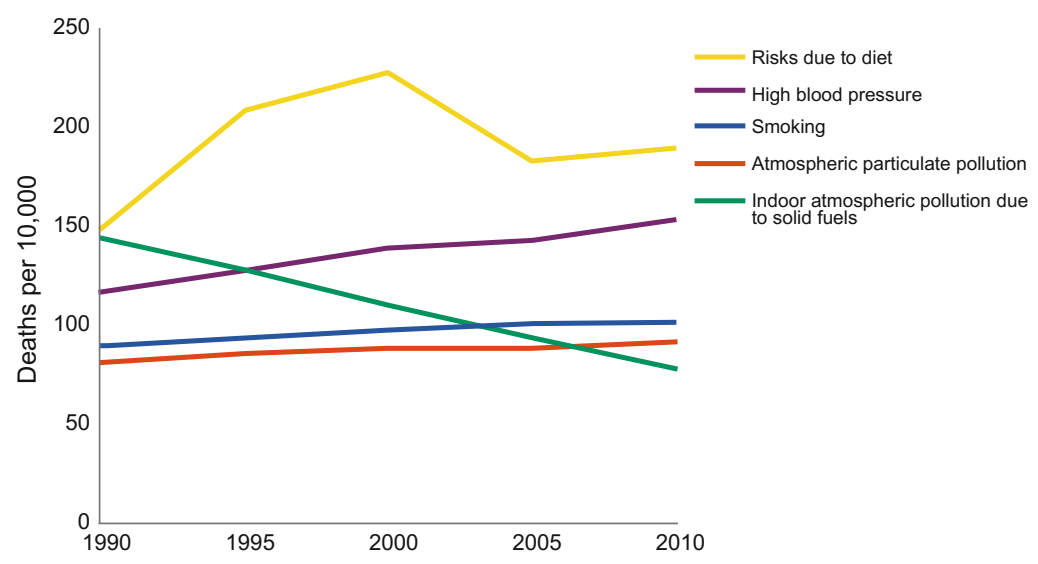

Fig. 4.1 Top five causes of death of residents in China. Data source Vivid Economics, referred from Institute for Health Metrics and Evaluation (2014)

\subsubsection{Losses from Injury to Health Caused by Atmospheric Pollution in China Account for $3-12 \%$ of GDP}

Economic activity can improve citizens' income and increase well-being, but the associated atmospheric pollution causes losses in terms of quality of life. A balance must be reached between economic benefits and losses. However, health losses cannot be directly measured in the same way as economic output if there is no quantification of loss of health. Previous experience shows that, if health effects can be economically quantified in a financial index that represents losses caused by the death of a person, this reflects the true cost of economic development, and can act to promote improvements in air quality. ${ }^{1}$

\section{Atmospheric pollution losses in the European Union}

Based on international standards, the air quality in EU countries is excellent. However, in 2012, the losses from primary pollutants generated by industry and energy generation still accounted for between $0.3 \%$ and $1 \%$ of GDP

\footnotetext{
${ }^{1}$ There are also many people who object to using money to measure the value of life, but for the purpose of balancing interests, this measure is still necessary.
}

(European Environment Agency, 2014). Figure 4.2 shows estimated hazard costs per ton of pollutants in Europe. In Europe, the hazards of $\mathrm{CO}_{2}$ cost 9.8-38.1 €/t (2005 prices), while the hazards of $\mathrm{PM}_{10}$ cost $23,000-67,000 € / \mathrm{t}$. Other pollutants besides particulate matter also need to be noted; in particular, the hazard cost of heavy metal and organic pollutants per unit weight far exceeds that of particulate matter pollution, though the quantity of these pollutants is less. The hazard that they represent overall is therefore less than that presented by particulate matter.

\section{Estimate of health-related losses caused by atmospheric pollution in China}

China faces worse pollution than other countries. In the main cities in China, the average concentration of $\mathrm{PM}_{10}$ and sulphur dioxide is respectively 5 times and 12 times the reference value (Nielson and Ho 2013) issued by the WHO in 2009. Significant research has shown that air pollution and energy structure have a direct relationship. In recent years, various methods have been adopted in many studies to assess health-related losses in China.

The China 2030 Report, jointly issued by the Development Research Center of the State Council and the World Bank in 2013, estimated that the health-related losses caused by $\mathrm{PM}_{10}$ were equivalent to $2.8 \%$ of the GNI in 2009 , 


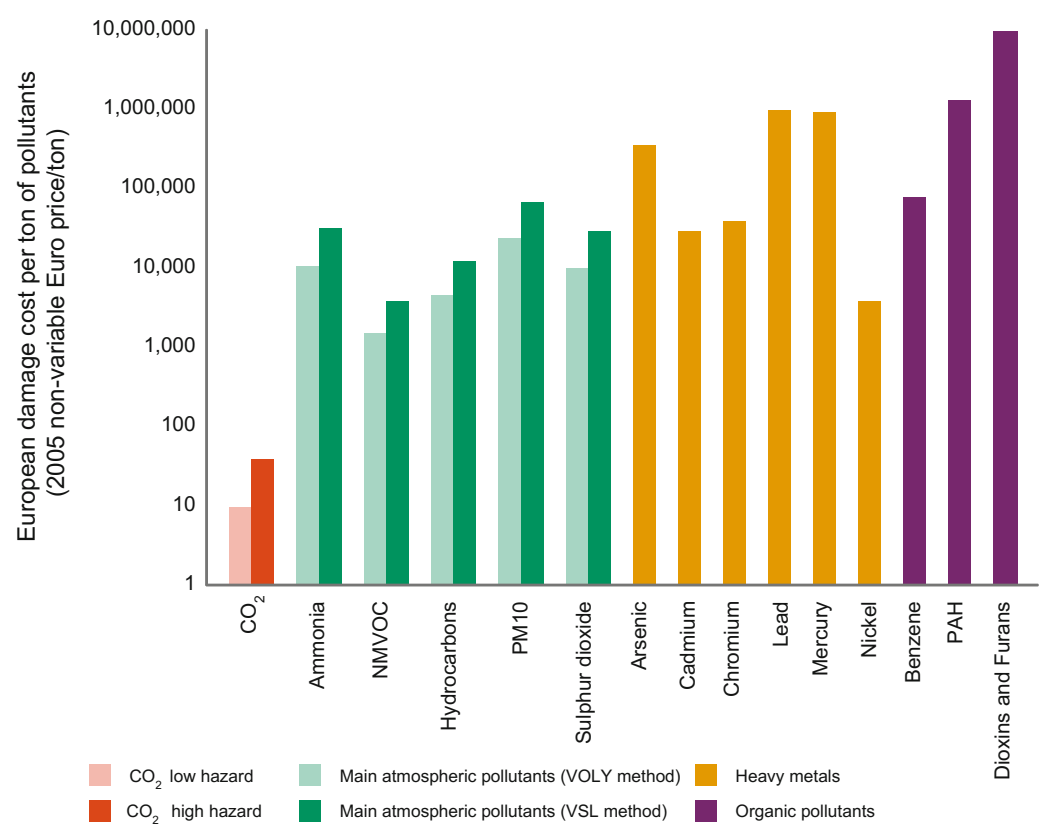

Fig. 4.2 Hazard cost estimation for main pollutants in Europe. Note Damage calculations apply for Europe only. Data source Vivid Economics, referred from (European Environment Agency, 2014)

calculated based on the two basic parameters of deaths caused by particulate matter discharge and the amount of money that people are willing to pay to reduce the risk of disease.

The New Climate Economy Report issued by the Global Commission on Economy and Climate in 2014 estimated that the economic loss caused by deaths of people due to $\mathrm{PM}_{2.5}$ in China in 2010 was equivalent to $9.7-13.2 \%$ of GDP, with a median value of around $12 \%$ of GDP. This result was obtained by multiplying three values: deaths caused by $\mathrm{PM}_{2.5}$, economic value of deaths and per capita GDP. The economic value of deaths was obtained by converting the value of statistical life (VSL) used in the European Union, adjusted for per capita income. In other words, the economic value of deaths will grow together with the growth of per capita GDP. Data for deaths caused by $\mathrm{PM}_{2.5}$ was sourced from the WHO's 2010 Global Burden of Disease Study.

Matus et al. (2011) estimated the economic loss caused by atmospheric pollution. This paper calculated the health hazard caused by $\mathrm{PM}_{10}$ and ozone, and the results show that in 2005 the economic losses caused by health hazards due to
$\mathrm{PM}_{10}$ accounted for around $6 \%$ of GDP. This paper adopted the multi-department CGE model to calculate the losses due to atmospheric pollution health damage between 1970 and 2005, taking into account the cost of related treatment, reduced working capacity and extra holidays taken. In 2005, around $60 \%$ of the losses were due to death, $10 \%$ due to the cost of treatment and $30 \%$ from other economic losses.

If other pollutants are brought into the equation, the economic losses of atmospheric pollution in China become even higher. These studies only consider particulate matter (PM), including the larger $\mathrm{PM}_{10}$ with a diameter of 10 microns and the smaller but more harmful $\mathrm{PM}_{2.5}$. In fact, the hazards of other pollutants such as sulphur dioxide and nitrogen dioxide are also severe.

In general, the difficulties encountered in research into the economic quantification of the losses caused by atmospheric pollution in China cause a lot of variation: the research methods, concerns and assessment standards are different, and the research results are also uncertain. Generally speaking, the economic loss caused by atmospheric pollution in China is massive, 


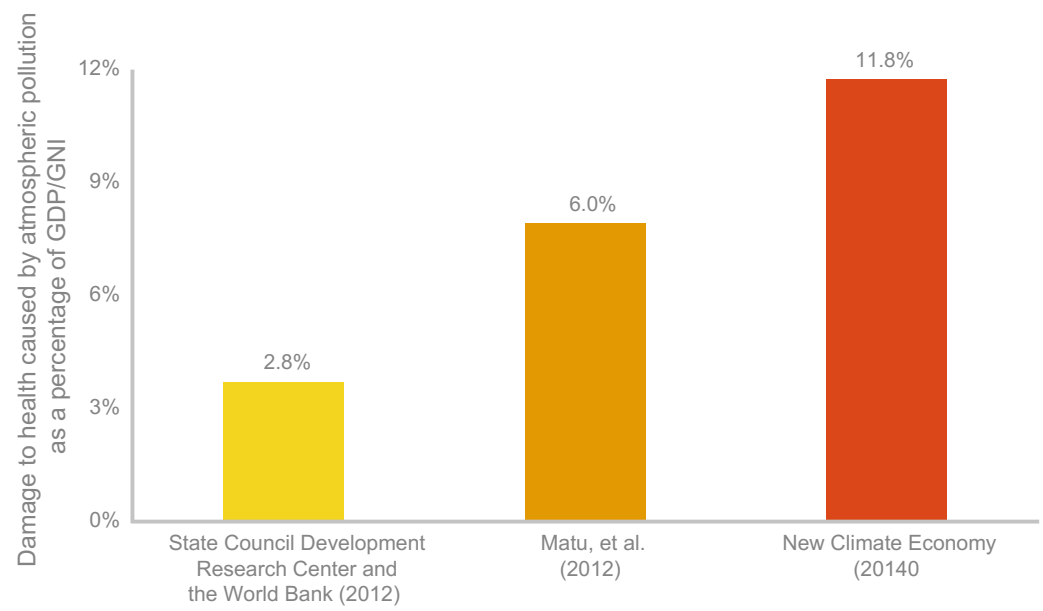

Fig. 4.3 Economic loss caused by atmospheric pollution as a percentage of GDP. Data source The State Council Development Research Center and the World Bank 2012, Matus et al. 2012; Global Economy and Climate Commission, 2014

equivalent to between $3 \%$ and $12 \%$ of GDP. Based on the results of these studies, in 2014, atmospheric pollution caused a loss of between $\$ 300$ billion and $\$ 1200$ billion in China. Given that the International Energy Agency estimated that China's energy supply needed $\$ 300$ billion of investment annually up to 2035, this gives a clear indication that improving air quality would pay for itself (Fig. 4.3).

\section{Other unfavourable effects of atmospheric pollution}

Atmospheric pollution not only causes direct harm to health and economic losses, it also reduces China's capital labour reserves and reduces productivity. This results in a "haircut" being applied in terms of the actual economic benefits of the particularly labour-centred approach to economic activities that China relies on. In addition, the investment attracted by the 12th Five-Year Plan and the political targets put forward during the 3rd Plenary Session of the 18th CPC Central Committee will also be affected. The implementation of policies for expanding urbanisation, developing the service industry, reducing inequality, improving social insurance, etc. will become harder to achieve, as shown in Fig. 4.4.

\subsection{The Environmental Value of Natural Gas as a Substitute for Coal}

The environmental value of natural gas stems from the fact that it is a clean energy substitute for coal. Coal production, transportation and usage cause serious environmental pollution, and result in tremendous direct and indirect external economic losses. However, as the costs of environmental pollution in China are accounted for as external economic losses, market entities causing environmental pollution consistently fail to pay the price of environmental pollution themselves. Similarly, the environmental benefits of replacing coal and oil with natural gas are not reflected in natural gas's market value, since the costs of failing to make the replacement are not being internalised.

\subsubsection{Environmental Pollution and Economic Losses Incurred During Coal Production}

Environmental pollution generated during coal production manifests as damage to and 


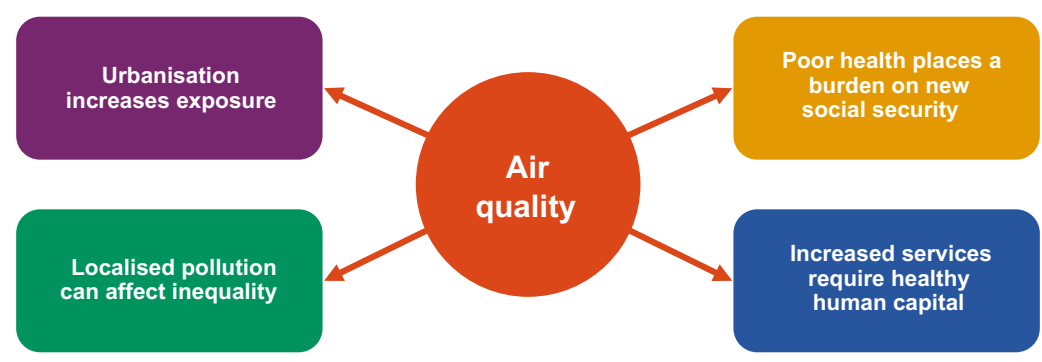

Fig. 4.4 Further effects of atmospheric pollution

appropriation of land, and pollution of water resources and the atmosphere.

Underground mining causes surface subsidence; mining areas suffer from ponding, flooding and salinisation, which accelerate water and soil erosion; and desertification causes damage to surface infrastructure to differing degrees. Open coal mining peels off the topsoil and rock stratum covering the coal bed, destroying land resources, and discharges spoil onto adjoining land. Coal spoil piles up and buries land resources. Based on relevant data, extraction of 10,000 tons of coal will cause surface subsidence of an area of $0.2 \mathrm{hec}$ tares, requiring relocation of two residents, while associated spoil occupies 0.01 hectares. The economic losses caused by land resource damage due to extraction of one ton of coal are thus CNY 65 .

During the mining process, the scale of extraction grows and even larger quantities of mine water are discharged, causing pollution of the aquatic environment around mines; meanwhile, the water table drops, causing subsidence. The commonly used coal washing process results in large quantities of water that contains high concentrations of sludge, silt and harmful heavy metal ions. Large amounts of harmful substances (especially heavy metal ions) contained in the coal spoil heaps leach out due to rainfall and enter the ecosystem. Based on relevant data, extraction of one ton of coal results in the discharge of 2.3 tons of mine water, 0.35 tons of industrial waste water, 0.05 tons of coal washing water, and 0.04 tons of other waste water, resulting in economic losses estimated at CNY 10 per ton of coal.

The greenhouse effect of marsh gas (the main ingredient of which is $\mathrm{CH}_{4}$ ) released during coal extraction is 21 times that of $\mathrm{CO}_{2}$, making this one of the main gases responsible for global warming. Large quantities of hazardous gases such as $\mathrm{SO}_{2}, \mathrm{CO}_{2}, \mathrm{CO}$ etc. produced by spontaneous combustion of coal spoil also affect the atmospheric environment. Based on relevant data, extraction of one ton of coal on average results in the discharge of $10 \mathrm{~m}^{3}$ of gas, equivalent to a discharge of $138 \mathrm{~kg}$ of $\mathrm{CO}_{2}$, and the estimated economic loss caused by atmospheric pollution produced by extraction of one ton of coal is CNY 15.

Economic losses caused by environmental pollution during coal production per ton of coal extracted are around CNY 90.

\subsubsection{Environmental Pollution and Economic Loss During Coal Transportation}

The geographical distribution of coal production and consumption in China is highly unbalanced, with coal production bases being distributed mainly in the northern and western regions, while coal consumption is mainly distributed in eastern and coastal areas, determining the basic pattern of transportation: northern coal to the south, and western coal to the east. The average distance coal is transported by rail is $552 \mathrm{~km}$.

Coal in China is transported over long distances, and passes from the coal stores or coal yards of mines to trains (or vehicles or vessels) and then reaches large thermal power generation coal yards, industrial coal consumption enterprise coal yards and fuel company coal yards of various sizes. As coal storage, loading and 
transportation facilities are usually not integrated, the lack of flow regulation exacerbated by poor management results in serious pollution of the surroundings at all stages of coal storage, handling and transportation.

The spontaneous combustion of mined coal not only happens in coal yards, but also after loading on lorries or vessels. During open stacking, handling and transportation of coal, the coal dust contaminates wide areas and causes serious pollution. Spraying in open coal yards during loading and unloading to cause coal dust to settle results in pollution of bodies of water.

Based on relevant data, there is an annual discharge of between 200,000-300,000 tons of harmful gas due to spontaneous combustion of coal in China, while 10 million tons of coal dust is produced during coal storage and 11 million tons of coal dust is generated during coal transportation. The estimated economic losses caused by pollution from transportation of each ton of coal are thus CNY 20.

\subsubsection{Estimates of Environmental Pollution and Economic Losses Arising from Coal Use}

Direct combustion of large amounts of coal has caused serious damage to the environment in China, while it is also the main cause of environmental pollution.

$\mathrm{SO}_{2}$ discharge and acid rain have serious effects on human health and vegetation, and cause deforestation, damage to buildings and metal corrosion. Based on calculations made by various institutions, the economic loss caused by the discharge of one ton of $\mathrm{SO}_{2}$ is as high as CNY 7000.

$\mathrm{CO}_{2}$ discharge and the greenhouse effect seriously threaten global ecosystems and the survival of mankind, causing shrinking forests, land salinisation, desertification, extreme weather events, etc. Based on the cost of carbon sequestration, the estimated economic loss caused by the discharge of one ton of $\mathrm{CO}_{2}$ is CNY 110 .

$\mathrm{NO}_{\mathrm{X}}$ discharges have serious effects on human health and cause a series of diseases and photochemical reactions, in addition to damaging ecosystems. Based on calculations made by various institutions, the economic loss caused by discharge of one ton of $\mathrm{NO}_{\mathrm{X}}$ is as high as CNY 5000.

Dust emissions have an effect on human health and discharge of dust into the atmosphere will reduce atmospheric cleanliness and affect plant photosynthesis etc. Based on calculations made by various institutions, the economic loss caused by discharge of one ton of dust is as high as CNY 200,000.

Based on calculations of coal combustion pollutant discharge quantities, the economic loss caused by the pollution produced by one ton of raw coal is CNY 830 (Table 4.1).

\subsubsection{Environmental Value Assessment for Natural Gas Substituting Coal}

The process of coal production, transportation and use results in serious environmental pollution. The estimated economic loss incurred is 380$940 \mathrm{CNY} / \mathrm{t}$, of which production accounts for $90 \mathrm{CNY} / \mathrm{t}$, transportation accounts for $20 \mathrm{CNY} / \mathrm{t}$ and usage accounts for $295-830 \mathrm{CNY} / \mathrm{t}$.

$\mathrm{CO}_{2}$ and other micro pollutants are discharged during the natural gas usage process. Calculated based on a discharge of $2.5 \mathrm{~kg} \mathrm{CO}_{2}$ per $\mathrm{m}^{3}$ natural gas, the economic loss caused by the pollution due to natural gas is $0.3 \mathrm{CNY} / \mathrm{m}^{3}$.

Based on calorific value and efficiency of coal and natural gas, and calculated for $550 \mathrm{~m}^{3}$ natural gas replacing one ton of coal, the natural gas environmental value compared to coal which is subjected to similar emissions restrictions is 0.4 1.4 $\mathrm{CNY} / \mathrm{m}^{3}$ and $1.4 \mathrm{CNY} / \mathrm{m}^{3}$ under conditions of dispersed coal use.

\subsection{Social Value of Natural Gas as a Substitute for Coal}

Besides environmental losses, coal production, transportation and consumption processes all cause non-economic losses to the population, for instance non-economic losses involving mental 
Table 4.1 Calculation table for the economic loss caused by pollution produced by one ton of raw coal

\begin{tabular}{|c|c|c|c|c|c|c|}
\hline \multirow[t]{2}{*}{ Emission } & \multicolumn{2}{|c|}{ Discharge quantity $(\mathrm{kg})$} & \multirow{2}{*}{$\begin{array}{l}\text { Unit loss } \\
(\mathrm{CNY} / \mathrm{kg})\end{array}$} & \multicolumn{2}{|c|}{ Economic loss (CNY) } & \multirow[t]{2}{*}{ Remarks } \\
\hline & $\begin{array}{l}\text { Near zero } \\
\text { emissions }\end{array}$ & $\begin{array}{l}\text { Distributed } \\
\text { combustion }\end{array}$ & & $\begin{array}{l}\text { Concentrated } \\
\text { combustion }\end{array}$ & $\begin{array}{l}\text { Distributed } \\
\text { combustion }\end{array}$ & \\
\hline $\mathrm{CO}_{2}$ & 2455 & 2455 & 0.11 & 270 & 270 & $\begin{array}{l}\text { Calculated based on carbon } \\
\text { exchange value }\end{array}$ \\
\hline $\mathrm{NO}_{\mathrm{X}}$ & & 5.40 & 5 & & 27 & Calculated based on pollution loss \\
\hline $\mathrm{SO}_{2}$ & & 10.40 & 7 & & 73 & Calculated based on pollution loss \\
\hline Dust & & 2.30 & 200 & & 460 & Calculated based on pollution loss \\
\hline Total & & & & 295 & 830 & \\
\hline
\end{tabular}

and physical suffering, such as that due to the pain caused by disease suffered by the victim, and the pain caused to the relatives due to the death of a loved one.

Social losses are calculated based on difference in willingness to pay and human capital. Willingness to pay refers to readiness to pay or a desire for compensation ascertained through research, the calculation of which includes bidding gaming methods, comparison gaming methods and the Delphi method. Human capital refers to the monetary loss connected with health, including increased losses and medical expenses due to premature death, illness or medical leave and other factors.

\subsubsection{Social Loss of Coal Production}

The coal industry is the industry with the greatest number of fatal accidents in China - annual coal mine fatalities had reached around 6000-7000, but dropped to nearly 4000 by 2007 . Accidents in coal mines account for $85 \%$ of workplace fatalities in China's mining industry, and coal mining accounts for $50 \%$ of all mining fatalities, the highest rate in the country. Apart from this, pneumoconiosis, an occupational disease related to coal production, has very serious consequences on health.

\subsubsection{Social Loss of Coal Use}

Environmental pollution caused by coal use seriously affects people's health. $\mathrm{SO}_{2}$ emissions have obvious effects on the respiratory system, irritating the respiratory mucosa, resulting in acute and chronic inflammation of the respiratory tract. Long-term inhalation of $\mathrm{SO}_{2}$ will lead to fibre hyperplasia of lung tissue cell walls as well as emphysema and bronchial asthma. Smoke dust discharge is a serious problem too. The dust consists of particulates which can become suspended in the atmosphere for a long time, and at any time it can be directly inhaled into the respiratory tract. These small particulates are a carrier of bacteria, viruses and metallic particles, and bring harmful pathogenic bacteria and toxic particles into the human respiratory system and the alveoli, inducing allergic rhinitis, bronchitis and bronchial asthma, and even malignant tumours.

\subsubsection{Social Value Assessment of Natural Gas as a Substitute for Coal}

Based on the functional relationships between death rate and the incidence (dose-response function) of certain diseases outlined in Atmospheric Pollution in Large and Medium-Sized Cities of China issued by the World Bank, the contribution of coal and natural gas use to atmospheric pollution was evaluated, while considering the loss of life caused by mining accidents and the social losses associated with occupational diseases encountered in the coal production process, providing an estimated external environmental benefit to society of natural gas of around $0.4 \mathrm{CNY} / \mathrm{m}^{3}$ (Table 4.2). 
Table 4.2 Dosage-effect function of inhalable particulate matter $\mathrm{PM}_{10}$

\begin{tabular}{|c|c|c|c|c|}
\hline \multirow[t]{2}{*}{ Item } & \multirow[t]{2}{*}{ Unit } & \multirow[t]{2}{*}{ Value } & \multicolumn{2}{|c|}{ Unit value orientation (CNY) } \\
\hline & & & $\begin{array}{l}\text { Human capital } \\
\text { method }\end{array}$ & $\begin{array}{l}\text { Willingness to pay } \\
\text { (WTP) method }\end{array}$ \\
\hline Mortality & Person & 6 & 100,000 & 500,000 \\
\hline Respiratory disease outpatient rate & Case & 12 & 4000 & 5200 \\
\hline Emergency cases & Case & 235 & 400 & 520 \\
\hline Restricted activity days & Day & 57,500 & 40 & 52 \\
\hline $\begin{array}{l}\text { Lower respiratory tract infection/ } \\
\text { paediatric asthma }\end{array}$ & Case & 23 & 200 & 260 \\
\hline Asthma & Case & 2068 & 60 & 78 \\
\hline Chronic bronchitis & Case & 61 & 80,000 & 104,000 \\
\hline Respiratory disease symptoms & Case & 183,000 & 10 & 13 \\
\hline
\end{tabular}

\subsection{China's Achievements in Energy Conservation and Emissions Reduction}

Thanks to technical progress and greater social awareness, China has significantly enhanced its energy conservation and emissions reduction work in recent years. The results show that energy conservation and emissions reduction resulted in significant direct and indirect benefits being achieved with limited input, providing empirical support for the further development of clean energy in China.

\subsubsection{Targets and Main Measures for Sulphur Dioxide Emission Reduction During the Period of the 12th Five-Year Plan}

In recent years, China has attached great importance to energy conservation and emissions reduction, and has strengthened the intensity of energy conservation and emissions reduction work, with stated targets becoming binding indexes listed in the Five-Year Plan and government planning. For example, the 11th Five-Year Plan specified that sulphur dioxide emissions between 2006 and 2010 should be
$10 \%$ lower than those in 2005. Judging from the actual achievements, the implementation of these emission reduction works has seen good results.

In order to achieve the sulphur dioxide emissions reduction targets during the 11th Five-Year Plan period, two main policies were adopted by the Chinese government.

- All newly-built coal-fired power generation plants were required to be fitted with flue gas desulphurisation facilities conforming to specific standards, while most of the old power generation plants were required to undergo retrofitting to meet desulphurisation standards. After the reforms, the coal-fired power station flue gas desulphurisation capacity was enhanced to $83 \%$ in 2010 from the $12 \%$ adopted in 2005. Flue gas desulphurisation conversion costs are low. The flue gas desulphurisation cost of a 6 million-watt power plant is only around $3.8 \%$ of the construction cost, and operational costs are increased by $2.4 \%$ - costs that are offset by government subsidies.

- Small, inefficient power generation plants were to be shut down. At the end of 2005, low-use and highly polluting small power plants accounted for one third of national energy production. By replacing these with large power generation plants, costs were reduced by a factor of 2 or 3 per million 


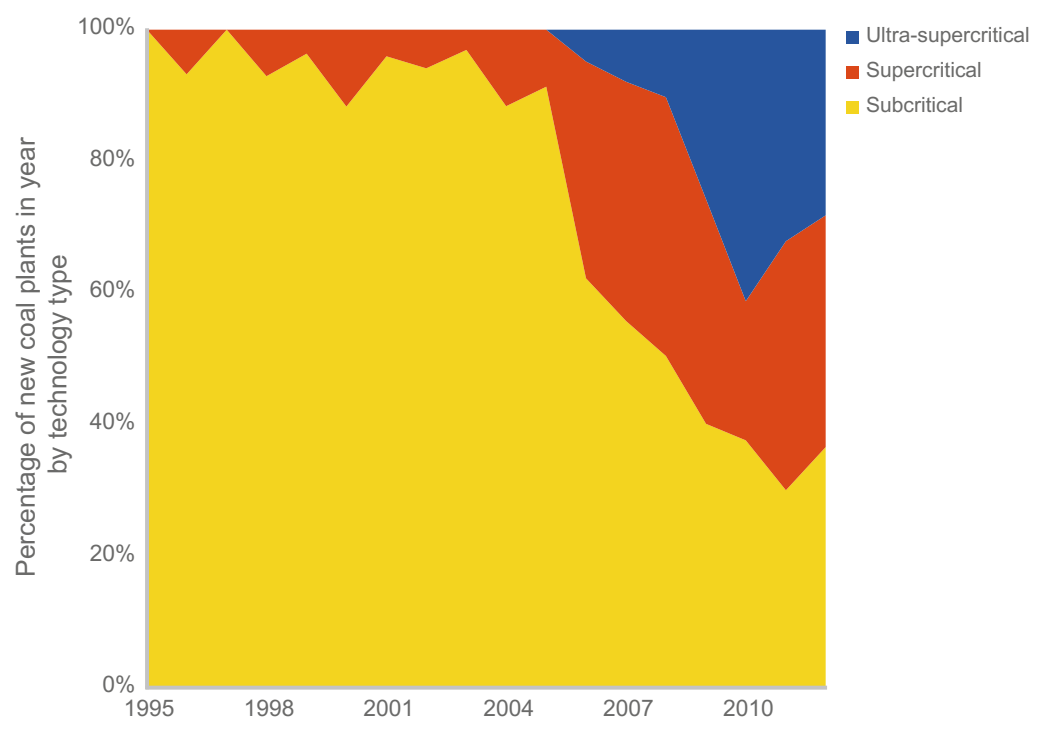

Fig. 4.5 Proportion of new technology use in newly built coal-fired power stations in China. Source Vivid Economics, based on PIRA database

watts. Since 2004, the average coverage of new power generation plants has doubled. At the same time, most of the large new power generation plants have adopted more efficient technology, as shown in Fig. 4.5. Based on the shutdown policy for small power plants, 59 billion watts of small power plants were closed during the 11th Five-Year Plan period and replaced by larger power plants.

\subsubsection{Emissions Reduction Results Achieved During the 11th Five-Year Plan Period}

The goals of reducing sulphur dioxide emissions were achieved. The power sector accounted for $54 \%$ and $28 \%$ of the total sulphur dioxide emissions respectively in 2005 and in 2011, growth in sulphur dioxide emissions being much slower than that of other pollutants, such as nitrogen oxides and particulate matter. A study conducted by Harvard University and Tsinghua University shows that the sulphur dioxide emission reduction policy achieved a major effect with a low macroeconomic cost, and is expected to save between 12,000 and 74,000 lives every year, which is equivalent to CNY 8-400 billion (Nielson and Ho, 2013). This policy shows that China can achieve greater benefits (synergically speaking) by improving atmospheric quality, while greater losses result if atmospheric pollution is not controlled (Fig. 4.6).

\subsubsection{Enormous Potential for Natural Gas to Substitute for Coal in Industrial Fuel and Residential Heating}

Considered from the point of view of pollutant source, industrial and domestic coal use are now major contributors. In recent years, the level of pollution prevention and control technology in coal-fired power generation plants in China has improved significantly, with the proportion of pollution produced during power generation sharply dropping, the proportion of pollution produced by transportation being relatively low, and emissions improving year by year. This is primarily as a result of improved vehicles. For example, new urban vehicles in China must comply with the Europe IV standard, which 


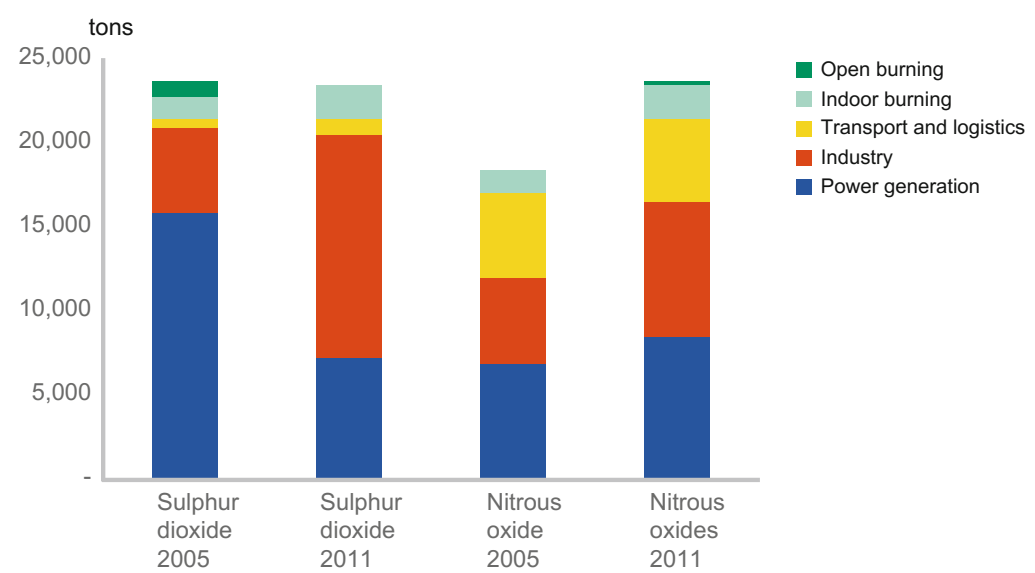

Fig. 4.6 Reduction of sulphur dioxide and nitrogen oxides emission during the 11th Five-Year Plan period. Data source: Vivid Economics, referred from Nelson and Ho (2013)

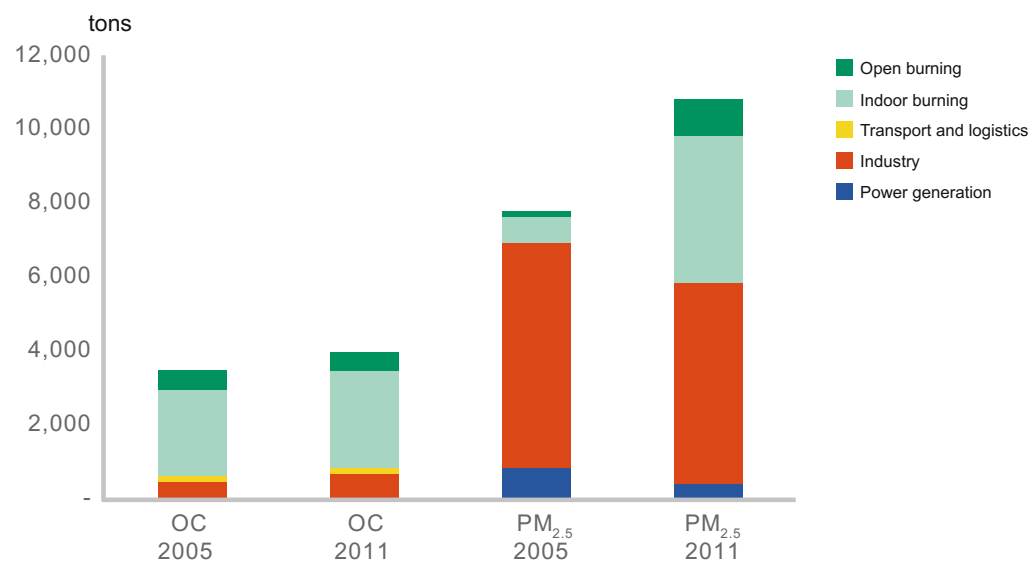

Fig. 4.7 Change in the sources of $\mathrm{PM}_{2.5}$ and $\mathrm{OC}$ (organic carbon) during the 11th Five-year Plan

greatly reduces automobile exhaust pollutant emissions. In terms of main pollutant sources such as sulphur dioxide, nitrogen oxides, $\mathrm{PM}_{2.5}$ and organic carbon (OC), etc., industrial and residential use are the main sources of emissions (Fig. 4.7).

Conversion from coal to natural gas in industrial and residential use is a feasible pollution prevention and control measure. Different methods have been adopted for the control of production-related and residential pollutant emissions and the control of sulphur dioxide emissions during the 11th Five-Year Plan. This is because the dispersal of industrial and residential users and their relatively small scale restricts their ability to adopt the same end technology on a significant scale. In contrast, the average scale of new power generation stations in China has tripled since 2004, and there are now 1425 new power stations. Despite the quantity being significant, it is still small compared to the quantity of industrial and residential user locations in China. Natural gas is suitable for small-scale applications, and this represents an economically valuable approach to reducing coal pollutant emissions from industrial production and residential heating. 
Open Access This chapter is licensed under the terms of the Creative Commons Attribution 4.0 International License (http://creativecommons.org/licenses/by/4.0/)), which permits use, sharing, adaptation, distribution and reproduction in any medium or format, as long as you give appropriate credit to the original author(s) and the source, provide a link to the Creative Commons license and indicate if changes were made.
The images or other third party material in this chapter are included in the chapter's Creative Commons license, unless indicated otherwise in a credit line to the material. If material is not included in the chapter's Creative Commons license and your intended use is not permitted by statutory regulation or exceeds the permitted use, you will need to obtain permission directly from the copyright holder. 